\title{
Adhesion to porcine squamous epithelium of saccharide and protein moieties of Lactobacillus fermentum strain 104-S
}

\author{
A. Henriksson and P. L. ConwaY* \\ Department of General and Marine Microbiology, University of Göteborg, Carl Skottbergs gata 22, \\ S-413 19 Göteborg, Sweden
}

(Received 5 March 1992; revised 16 June 1992; accepted 24 July 1992)

\begin{abstract}
The mechanism by which Lactobacillus fermentum strain 104-S adheres to porcine squamous epithelium was investigated by studying the adsorption to epithelial cells, and control surfaces, of radioactively labelled material released from the bacterial cells by ' water extraction. The released material was fractionated by gel filtration and the adsorption of pronase-sensitive and -resistant material in the various fractions to porcine gastric tissue and the control surfaces of polystyrene and immobilized bovine serum albumin (BSA) was determined. The fraction with affinity for the epithelium was characterized by enzymic degradation, periodate oxidation, lipid extraction, and protein and carbohydrate analyses. The adsorption pattern of radioactively labelled crude released material mimicked the adhesion of whole labelled cells to polystyrene and to gastric squamous tissue pieces. On fractionation, the pattern of adsorption to polystyrene and BSA was different from that obtained for the tissue pieces. Considerably less labelled pronase-stable material bound to surfaces of polystyrene and BSA, as compared with the tissue, suggesting that the pronase-resistant component has a tissue-specific affinity. After pronase treatment of the fraction of $M_{\mathrm{r}}$ about $20000(20 \mathrm{~K})$ containing labelled components with affinity for the epithelium, only saccharides were detected. Radioactivity was lost after hydrolysis with $\mathrm{HCl}$, and therefore this pronaseresistant labelled component must be a saccharide. It is concluded that protein moieties in the extract have an affinity for several surfaces, including polystyrene, and that saccharide moieties have a specific affinity for the gastric squamous epithelium.
\end{abstract}

\section{Introduction}

Lactobacillus spp. colonize the stomach of various mammals and birds (Smith, 1965). They have been shown to colonize especially the non-secreting part of the porcine stomach in vivo and to adhere to epithelial cells in vitro (Fuller et al., 1978). The lactobacillus cell wall is complex in its composition (Coyette \& Ghuysen, 1970) and several structures have been suggested to be involved in the adhesion of lactobacilli to tissue from various host animals. Sherman \& Savage (1986) proposed that the adhesion to rodent squamous tissue was mediated by macromolecules containing protein and lipoteichoic acid. In addition, carbohydrates were described as the determinant responsible for mediating adhesion of Lactobacillus sp. to squamous epithelial cells (Barrow et $a l ., 1980)$. A proteinaceous component has been shown to

* Author for correspondence. Tel. 46-31-418700; fax 46-31-826790.

Abbreviations: $20 \mathrm{~K}, M_{\mathrm{r}} 20000 ; 200 \mathrm{~K}, M_{\mathrm{r}} 200000$. mediate adhesion of an $L$. fermentum strain to rodent squamous cells in vitro (Conway \& Kjelleberg, 1989). Furthermore, Wadström et al. (1987) suggested that hydrophobic interaction mediated adhesion to porcine ileal epithelial cells and that protein components may be involved.

In a previous study using $L$. fermentum 104 strains (Henriksson et al., 1991), it was noted that $L$. fermentum 104-S had a greater affinity for the tissue, relative to other surfaces, when the adhesion was compared with strain $L$. fermentum 104- R. We concluded that the adhesion of L. fermentum 104-S was more tissue specific than that of strain 104-R. The determinant(s) responsible for adhesion of $L$. fermentum strain 104-S was shown to be pronase sensitive. When the bacterial cells in that study were pre-treated with pronase, the greatest reduction in adhesion was seen for the adhesion of bacterial cells to polystyrene. Although pronase induced a dramatic decrease in adhesion to the tissue, the adhesion of pronase-treated cells to tissue was greater than the low level of adhesion to polystyrene. The 
observation strongly indicated that proteins are the main adhesive determinant, but that other pronase-resistant components may be involved in the adhesion to tissue.

The aim of this study was to identify the bacterial component(s) which bind to porcine gastric squamous epithelium, and to characterize their chemical composition.

\section{Methods}

Bacteria. L. fermentum strain 104 was isolated from gastric epithelium of a 9-week-old pig (Henriksson et al., 1991). Rough and smooth colony variants, 104-R and 104-S, were detected on subculturing (R. Szewzyk and others, unpublished studies). For all experiments, $18 \mathrm{~h}$ pre-cultures of $L$. fermentum strains $104-\mathrm{S}$ and 104-R in Mann, Rogosa, Sharpe Lactobacillus broth (MRS; Difco) were inoculated (1\% of the final volume) into brain heart infusion broth (BHI; Oxoid) supplemented with $2 \%(\mathrm{w} / \mathrm{v})$ glucose. These growth conditions consistently yielded a cell suspension containing $100 \%$ or a maximum of $4 \%$ smooth cells for strains $104-\mathrm{S}$ and $104-\mathrm{R}$, respectively. Rough cells were never detected when 104-S was subcultured in BHI broth ( $R$. Szewzyk and others, unpublished studies). After $18 \mathrm{~h}$ of incubation in a candle jar, the cells were centrifuged for $10 \mathrm{~min}$ at $1600 \mathrm{~g}$ using a bench centrifuge and washed three times in PBS (phosphate buffer, $0.01 \mathrm{M}$, pH 7.2, containing $0 \cdot 14 \mathrm{M}-\mathrm{NaCl}$ ). For adhesion of whole cells, cells were radioactively labelled during growth in the $\mathrm{BHI}$ broth containing glucose, using $\left[{ }^{3} \mathrm{H}\right]$ thymidine as previously described (Henriksson $\boldsymbol{e t}$ al., 1991). In addition, cell surface components were radioactively labelled by reductive methylation of extracts from the whole cells, as outlined below. As a control that this procedure did not alter the adhesive determinant(s), whole cells were reductively methylated by suspending BHI + glucose broth grown washed cells $\left(1-2 \times 10^{9}\right.$ cells $\mathrm{ml}^{-1}$ ) in a radioactive labelling solution containing $100 \mathrm{~mm}$-Hepes Hanks buffer, $2 \mathrm{~mm}-\left[{ }^{3} \mathrm{H}\right]$ formaldehyde (specific activity $100 \mathrm{mCi}$ $\mathrm{mmol}^{-1}, 3.7 \mathrm{GBq} \mathrm{mmol}{ }^{-1}$; New England Nuclear) and $20 \mathrm{~mm}-$ $\mathrm{NaCNBH} 3$, and incubated at $22^{\circ} \mathrm{C}$ for $2 \mathrm{~h}$ (Jentoft \& Dearborn, 1979). Subsequently, the cells were centrifuged for $10 \mathrm{~min}$ at $1600 \mathrm{~g}$ using a bench centrifuge and washed three times in PBS.

Water extraction. After the last wash in PBS, the bacteral pellet was resuspended in water to yield the final cell concentration of $0.001 \mathrm{~g}$ cells (wet weight) $\mathrm{ml}^{-1}$. This cell suspension was incubated in a water bath $\left(37^{\circ} \mathrm{C}\right.$ ) for $1 \mathrm{~h}$, after which time it was vigorously mixed (Vortex tube mixer) for $5 \mathrm{~min}$ at room temperature, and then centrifuged on $25000 \mathrm{~g}$ for $30 \mathrm{~min}$. The supernatant was filter sterilized $(0.22 \mu \mathrm{m}$ filter, Millipore) and subsequently ultrafiltered (10000 $M_{\mathrm{r}}$ filter, Filtron) at $5000 \mathrm{~g}$ to remove low- $M_{\mathrm{r}}$ material. The retentate was diluted in a volume of $\mathrm{PBS}$ corresponding to 0.18 times the original volume of water. This material is referred to as the extracted material. For radioactive labelling of this extracted material, the retentate was diluted with the labelling solution instead of water, and the labelling performed as outlined above. After the labelling, the material was concentrated by ultrafiltration as outlined above. The retentate was resuspended and then washed three times in water. After the last wash, the retentate was diluted in PBS to yield the original volume prior to storage at $-20^{\circ} \mathrm{C}$. Radioactivity was measured using a liquid scintillation counter (Beckman) after addition of Ready-safe (Beckman) scintillation fluid $(3 \mathrm{ml})$ to $20 \mu \mathrm{l}$ aliquots.

Fractionation of extracted material. The extracted material was fractionated by gel filtration using Sephadex 200 SF (Pharmacia) packed in a XK $26 / 40$ column (Pharmacia) and a flow rate of $1.1 \mathrm{ml}$ $\mathrm{cm}^{-2} \mathrm{~h}^{-1}$. The eluate was collected in $2 \mathrm{ml}$ fractions. All material was fractionated at $5^{\circ} \mathrm{C}$ using PBS as the mobile phase. Radioactivity was measured as described above, and the fractions were stored at $-20^{\circ} \mathrm{C}$.

Adhesion of cells and adsorption assay. Adhesion of radioactively labelled whole cells to porcine squamous gastric tissue pieces and polystyrene was measured as previously described (Henriksson et al., 1991). In brief, radioactively labelled washed whole cells were incubated $\left(37^{\circ} \mathrm{C}\right)$ with tissue pieces for $15 \mathrm{~min}$. Unattached or loosely attached cells were removed by washing in PBS and the number of adhering bacteria was enumerated by quantifying the amount of radioactivity remaining on the tissue. For adsorption of the radioactively labelled extracted material, aliquots of the crude or fractionated material ( $\leq 10000$ d.p.m.) were added to tissue pieces or polystyrene, and the amount of radioactivity which adsorbed to the surfaces was assayed as for the whole labelled cells.

Enzyme treatments. A pronase solution (Calbiochem; $1 \mathrm{mg} \mathrm{ml}^{-1}$ in PBS) was added to the crude extracted material $(1 \mathrm{ml})$, to give a final concentration of $0.5 \mathrm{mg}$ pronase $\mathrm{ml}^{-1}$. The mixture was incubated at $37^{\circ} \mathrm{C}$ for $1 \mathrm{~h}$. The fractionated material was also exposed to a polynuclease digestion by adding $100 \mu$ of a nuclease solution $(10 \mathrm{mg}$ ribonuclease, $2.5 \mathrm{mg}$ deoxyribonuclease per $\mathrm{ml}$ PBS) to gel filtration fractions $56-60$ (see Fig. 1), to give a final concentration of $0.1 \mathrm{mg}$ ribonuclease $\mathrm{ml}^{-1}, 0 \cdot 1 \mathrm{mg}$ deoxyribonuclease $\mathrm{ml}^{-1}$. The material was incubated at $37^{\circ} \mathrm{C}$ for $1 \mathrm{~h}$. All enzyme-treated mixtures were fractionated as described above, and the radioactivity remaining after the treatment was compared with a non-treated control. In addition, the amount of radioactivity which adsorbed to epithelium from fractionated pronase-treated extract was assayed as described above for the adsorption assay. In this case, the adsorption assay was performed on ice to prevent enzyme activity during the assay.

Chemical treatments. The effect of metaperiodate oxidation was studied by adding $1 \mathrm{ml} 0.02 \mathrm{M}$-sodium metaperiodate in $0.1 \mathrm{M}$ citrate/phosphate buffer ( $\mathrm{pH} 4.5$ ) to an equal volume of the crude extracted material. The mixture was incubated in the dark at $37^{\circ} \mathrm{C}$ for $1 \mathrm{~h}$, and subsequently fractionated as described above. The extracted material was also exposed to $\mathrm{HCl}$ hydrolysis by initially concentrating a $2 \mathrm{ml}$ sample by ultrafiltration $\left(10000 M_{\mathrm{r}}\right.$ filter; Filtron) at $5000 \mathrm{~g}$. Aliquots of the retentate $(100 \mu \mathrm{l})$ were diluted with distilled water to $1 \mathrm{ml}$ and then mixed with an equal volume of $4 \mathrm{M}-\mathrm{HCl}$. The test tube was gassed with $\mathrm{N}_{2}$ and sealed prior to incubation in a boiling water bath for $2 \mathrm{~h}$. The treated material was fractionated as described above. In addition, lipids were extracted from fractionated pronase-treated crude extract. Fractions (56-60; Fig. 1), containing the labelled component with tissue affinity were extracted using chloroform and methanol (Folch et al., 1957).

Chemical analyses. The protein content was assayed as described by Bradford (1976), using BSA (bovine serum albumin) as the standard, by adding $0.2 \mathrm{ml}$ dye reagent concentrate (Bio-Rad) to samples of the various fractions $(0.8 \mathrm{ml})$. After gentle mixing and then incubation at room temperature for $10 \mathrm{~min}$, the absorbance was read at $595 \mathrm{~nm}$. The saccharide content was assayed using the phenol/sulphuric acid method of Dubois et al. (1956).

\section{Results}

\section{Adhesion of radioactively labelled whole cells and adsorption of extracted material}

When the adhesion of whole cells of $L$. fermentum 104-S and $L$. fermentum 104-R was compared, the former strain had a higher affinity for the tissue than the latter (Table 1). Furthermore, because addition of formaldehyde and 
Table 1. Adsorption pattern of radioactively labelled whole cells of L. fermentum strains $104 R$ and $104 S$ and material released from strain $104 \mathrm{~S}$

Relative affinity of the labelled components is expressed as the percentage of the ratio between values for tissue and polystyrene, and is shown as mean $\pm \mathrm{SD}$ ( $n=$ no. of individual experiments, each involving three assays).

\begin{tabular}{llccc}
\hline \hline & & \multicolumn{2}{c}{$\begin{array}{c}\text { Adsorbed material } \\
\text { (d.p.m.) }\end{array}$} & \\
\cline { 3 - 4 } $\begin{array}{c}\text { Bacterial } \\
\text { strain }\end{array}$ & $\begin{array}{c}\text { Labelled } \\
\text { component }\end{array}$ & Tissue & Polystyrene & $\begin{array}{c}\text { Relative } \\
\text { affinity (\%) }\end{array}$ \\
\hline $104 \mathrm{R}$ & Whole cells & 3013 & 39416 & $9 \pm 6(3)$ \\
$104 \mathrm{~S}$ & Whole cells & 5537 & 8992 & $53 \pm 18(3)$ \\
$104 \mathrm{~S}$ & $\begin{array}{l}\text { Whole cells* } \\
\text { Released } \\
104 \mathrm{~S}\end{array}$ & 5036 & 9707 & $52 \pm 15(2)$ \\
& material & 2458 & 4677 & $50 \pm 11(3)$ \\
\hline \hline
\end{tabular}

* Treated with formaldehyde and cyanoborohydride (control for reagents used for radioactive labelling).

cyanoborohydride to the whole cells had no effect on adhesion (Table 1), the technique of labelling by reductive methylation did not modify adhesion-mediating moieties. When the surfaces of tissue or polystyrene were exposed to the radioactively labelled extracted material, the relative affinity for these surfaces was consistent with that observed for whole cells. Fractionation of the extract by gel filtration showed that radioactively labelled components were detectable in many of the fractions; however, the void volume and components in fractions $56-60$ (the $20 \mathrm{~K}$ region) contained considerably more label (Fig. 1). The absorbance $(280 \mathrm{~nm})$ of the various fractions is also presented in Fig. 1. Incubation of the fractions with either epithelial pieces or the control surfaces of polystyrene or BSA revealed that the $20 \mathrm{~K}$ region contained material that had higher binding affinity for the tissue than for control surfaces (Fig. 2). In contrast, the adsorption of radioactivity to polystyrene or BSA in the $20 \mathrm{~K}$ range was low.

\section{Characterization of the labelled fractions with enhanced affinity for the tissue}

Pronase treatment of the crude labelled material prior to the fractionation resulted in no radioactively labelled material adsorbing to either tissue or polystyrene from the $200 \mathrm{~K}$ region (fractions 37-41) (Table 2). After metaperiodate treatment, only a small decrease was noted in the amount of radioactivity adsorbed to these surfaces from the $200 \mathrm{~K}$ fraction. Adsorption of material from the $20 \mathrm{~K}$ was more complex than that of the high$M_{\mathrm{r}}$ material. Pronase treatment of the crude material prior to the fractionation resulted in a decrease in the amount of radioactivity which adsorbed to the polystyrene. However, only a small decrease in the amount of

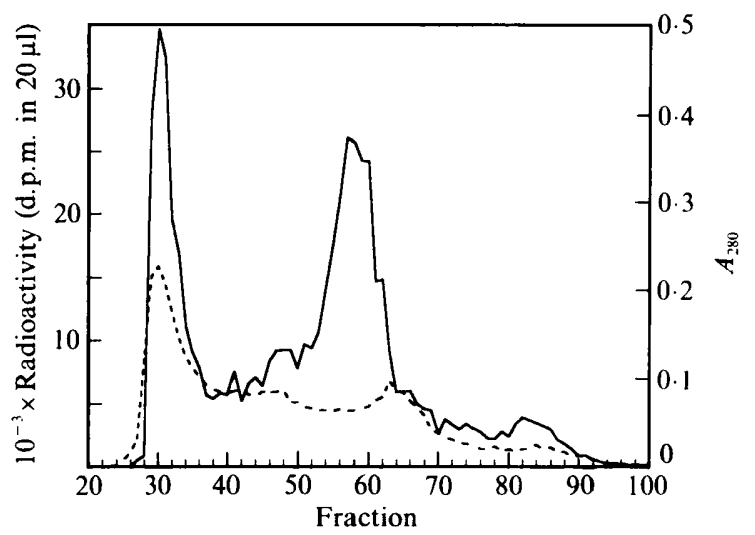

Fig. 1. Distribution of the radioactively labelled material $(-)$ and UV ( $280 \mathrm{~nm})$ absorbing material (----) when separated by gel filtration on Sephadex $200 \mathrm{SF}$. The void volume corresponded to fractions 28-32. Results are typical of three individual experiments.

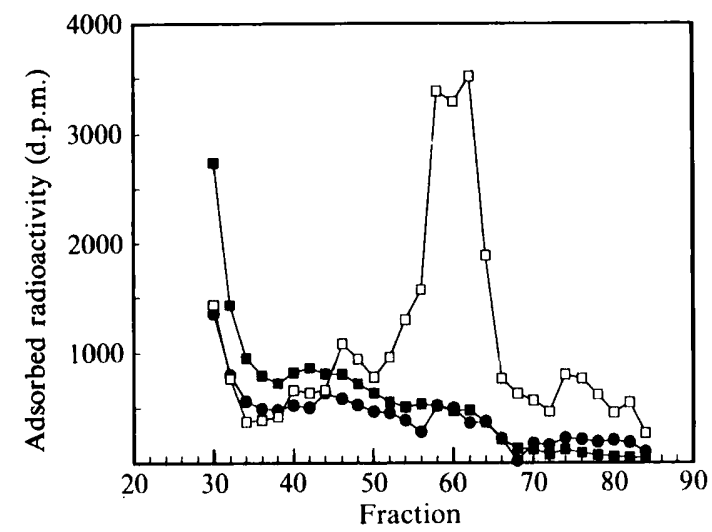

Fig. 2. Adsorption of radioactively labelled material in the $20 \mathrm{~K}$ region after gel filtration of the extracted material, to tissue ( $\square$ ), polystyrene $(\mathbb{G})$, or BSA-coated polystyrene $(\boldsymbol{O})$. Results are typical of three individual experiments that varied by $<10 \%$.

Table 2. Effect of pronase and periodate treatment on adsorption of fractionated material to tissue or polystyrene

Adhesion is measured as the percentage of adsorbed labelled material in relation to the non-treated control $\pm S D$. The numbers in parentheses represent the number of individual experiments, each involving three assays.

\begin{tabular}{lccccc}
\hline \hline & \multicolumn{4}{c}{ Adsorption index (\%) } \\
\cline { 2 - 3 } \cline { 5 - 6 } Treatment & $200 \mathrm{~K}$ & $20 \mathrm{~K}$ & & \multicolumn{2}{c}{ Tissue } \\
\cline { 2 - 6 } \cline { 5 - 6 } & & \multicolumn{2}{c}{ Polystyrene } & $20 \mathrm{~K}$ \\
\hline Pronase & $2 \pm 2(2)$ & $9 \pm 4(2)$ & $3 \pm 4(2)$ & $89 \pm 9(3)$ \\
Periodate & $96 \pm 18(2)$ & $88 \pm 17(2)$ & $65 \pm 8(2)$ & $78 \pm 24(3)$ \\
\hline \hline
\end{tabular}

pronase-treated material which adsorbed to tissue could be detected when the adsorption assay was performed at $0{ }^{\circ} \mathrm{C}$ (Table 2 ). Fifty percent less radioactively labelled material adsorbed to epithelium when the assay was 
Table 3. Effect of various treatments on the composition of the $200 \mathrm{~K}$ and $20 \mathrm{~K}$ fractions

\begin{tabular}{|c|c|c|c|c|c|c|}
\hline \multirow[b]{2}{*}{ Treatment } & \multicolumn{2}{|c|}{$\begin{array}{c}10^{-3} \times \text { Radioactivity } \\
\text { (d.p.m. in } 20 \mu \mathrm{l})\end{array}$} & \multicolumn{2}{|c|}{ 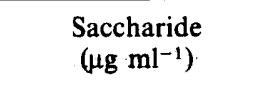 } & \multicolumn{2}{|c|}{$\begin{array}{l}\text { Protein } \\
\left(\mu \mathrm{g} \mathrm{m} l^{-1}\right)\end{array}$} \\
\hline & $200 \mathrm{~K}$ & $20 \mathrm{~K}$ & $200 \mathrm{~K}$ & $20 \mathrm{~K}$ & $200 \mathrm{~K}$ & $20 \mathrm{~K}$ \\
\hline None & $5 \cdot 4$ & 31 & 7.8 & 20 & $9 \cdot 2$ & $9 \cdot 0$ \\
\hline Pronase & 0.4 & 26 & $<3$ & 20 & $<1$ & $<1$ \\
\hline Periodate & $4 \cdot 6$ & 30 & $9 \cdot 0$ & 21 & 6.4 & $6 \cdot 1$ \\
\hline $\mathrm{HCl}, 100^{\circ} \mathrm{C}$ & 0.0 & $0 \cdot 0$ & $<3$ & $<3$ & $<1$ & $<1$ \\
\hline
\end{tabular}

carried out at $37^{\circ} \mathrm{C}$. Treatment of the $20 \mathrm{~K}$ fraction with polynucleases did not modify the $M_{\mathrm{r}}$ of the labelled component. After two-phase chloroform extraction of the $20 \mathrm{~K}$ region, all activity remained in the water phase.

\section{Chemical analysis of the fractions with affinity for tissue}

The protein and saccharide composition of the low $(20 \mathrm{~K}) M_{\mathrm{r}}$ fraction were analysed and compared with the high $(200 \mathrm{~K}) M_{\mathrm{r}}$ fraction. The protein contents of the two fractions were relatively uniform, in contrast to the saccharide content, which was 2.6 times higher in the low- $M_{\mathrm{r}}$ fraction (Table 3). The distribution of saccharides in the fractionated protease-treated material showed a concentration of saccharide in the $20 \mathrm{~K}$ region (Table 3 ). Pronase treatment of the crude material prior to gel filtration reduced the radioactivity in the $200 \mathrm{~K}$ fraction tenfold. This contrasted with the $20 \mathrm{~K}$ fraction, where the radioactivity remained relatively unaffected by pronase treatment (Table 3). Metaperiodate oxidation did not markedly change the radioactivity or the chemical composition of the fractions (Table 3). Hydrolysis in $\mathrm{HCl}$ resulted in no detectable radioactivity, saccharide or protein in the fractions (Table 3 ).

\section{Discussion}

It has been shown previously that the affinity of adhesion to squamous epithelium and the control surfaces of polystyrene and BSA were different for the two $L$. fermentum strains, 104-S and 104-R (Henriksson et al., 1991). In order to characterize the mechanism of bacterial adhesion to squamous epithelial cells, a method was required for extracting and labelling structures with affinity for the epithelium. After reductively methylating the water extracts from L. fermentum 104-S cells using radioactively labelled formaldehyde and cyanoborohydride, the adsorption of radioactive label in the extracts to polystyrene and tissue mimicked the adhesion of $L$. fermentum 104-S whole cells to these surfaces (Table 1). Consequently, one can conclude that adhesion-mediating determinants are present and labelled in the extract.
The resolution of the gel filration column used for fractionating covered the range from the void volume $\left(M_{\mathrm{r}} \geq 250000\right)$ to $M_{\mathrm{r}} 10000$. The void volume contained traces of several smaller $M_{\mathrm{r}}$ proteins and sugar when examined by SDS-PAGE (results not shown). The adsorption pattern of the fractions within the $M_{\mathrm{r}}$ range from $200 \mathrm{~K}$ to $10 \mathrm{~K}$ was different depending on the type of surface tested (Fig. 2). Although adsorption to polystyrene or BSA was relatively uniform for all fractions, compared to the adsorption to tissue, less radioactively labelled material adsorbed to polystyrene and BSA from the fraction containing the low $-M_{\mathrm{r}}$ components (Fig. 2).

The adsorption of radioactively labelled material to the tissue was heterogeneously distributed over the $M_{\mathrm{r}}$ range tested, with a peak of radioactive material absorbing from the $20 \mathrm{~K}$ region. From the results of the treatment of this $20 \mathrm{~K}$ material with nuclease, one can conclude that the radioactivity was not incorporated in a polynucleotide. The results from the chloroform extraction suggest that the radioactive component is nonamphiphilic and therefore not a lipid or lipoteichoic acid. Pronase treatment had virtually no effect on the radioactivity present in the $20 \mathrm{~K}$ region (Table 3 ); however, after pronase treatment of this fraction the material lost its affinity for polystyrene but retained affinity for the tissue (Table 2). These results imply that components other than lipids, lipoteichoic acid, nucleotides and proteins with an $M_{\mathrm{r}}$ of $20 \mathrm{~K}$ are involved in the specific adhesion of $L$. fermentum 104-S to the nonsecretory epithelium of the pig stomach, and that the extracted proteins are involved in a non-specific adhesion of the whole cells.

The greatest difference in affinity for the tested surfaces was between the $20 \mathrm{~K}$ (fractions 56-60) and $200 \mathrm{~K}$ (fractions 37-41) region. Pronase treatment of the $200 \mathrm{~K}$ material caused loss of most of the radioactivity (Table 3), and the remaining material did not bind to either polystyrene or tissue. Analysis of the pronasetreated high- $M_{\mathrm{r}}$ material show that not only did the protein content decrease, but also the amount of saccharides (Table 3), suggesting that saccharides associate with protein to form high- $M_{\mathrm{r}}$ glycoprotein in a native 
form. As the adsorption of metaperiodate-oxidized material to polystyrene was relatively unaffected compared to the control, one may conclude that saccharides are most probably not involved in the adsorption to polystyrene. It is also possible that saccharides which are not oxidizable using metaperiodate are involved. These results imply that high- $M_{\mathrm{r}}$ proteins are adsorbed, and probably mediate the adhesion of whole cells to polystyrene. As presented in Table 3, pronase treatment of the extracted material prior to fractionation resulted in the $20 \mathrm{~K}$ fractions being protein free $\left(<1 \mu \mathrm{g} \mathrm{ml}^{-1}\right)$, but still containing radioactivity. Furthermore, from the results of $\mathrm{HCl}$ hydrolysis one can conclude that the radioactivity is associated with the saccharides in the fraction and that the radioactive component in the $20 \mathrm{~K}$ fraction which binds to the tissue is a saccharide. One can hypothesize that it could be unacetylated amino sugars of this saccharide that are labelled.

The involvement of polysaccharide in adhesion of lactobacilli to porcine squamous gastric cells has been suggested previously (Barrow et al., 1980), because the lectin concanavalin A inhibited binding of lactobacilli to the porcine cells. In other lactobacillus-host systems, carbohydrates have been suggested to be involved in the adhesion both to murine stomach epithelium (Savage, 1972) and to the chicken crop (Brooker \& Fuller, 1975). Such carbohydrate materials have not previously been isolated, but visualized by transmission electron microscopy using lactobacillus cells stained with ruthenium red (Barrow et al., 1980). Additional studies using an antibody to the saccharide could be performed to confirm that the $20 \mathrm{~K}$ component is located on the cell wall.

Our results indicate that both saccharides and proteins play a role in adhesion of $L$. fermentum 104-S and that adhesion to tissue may involve both the saccharide and protein. This is in contrast to adhesion to polystyrene, which is mediated solely by protein.
This work was supported by the Swedish Farmers'Supply and Crop Marketing Association.

\section{References}

Barrow, P. A., Brooker, B. E., Fuller, B. E. \& Newrort, M. J. (1980). The attachment of bacteria to the gastric epithelium of the pig and its importance in the microbiology of the intestine. Journal of Applied Bacteriology 48, 147-154.

BRADFORD, M. (1976). A rapid and sensitive method for the quantitation of microgram quantities of protein utilizing the principle of protein dye binding. Analytical Biochemistry 72, 248-254.

BROOKER, B. E. \& FULLER, R. (1975). Adhesion of lactobacilli to the crop epithelium. Journal of Ultrastructure Research 52, 21-31.

Conway, P. L. \& KJelleberg, S. (1989). Protein mediated adhesion of Lactobacillus fermentum strain 737 to mouse stomach squamous epithelium. Journal of General Microbiology 135, 1175-1186.

CoyetTe, J. \& Ghuysen, J. M. (1970). Structure of the walls of Lactobacillus acidophilus strain 63 AM Gasser. Biochemistry 9, 29352943.

Dubois, M., Gilles, K. A., Hamilton, J. K., Rebers, P. A. \& Smith, F. (1956). Colorimetric method for determination of sugars and related substances. Analytical Chemistry 28, 350-356.

Folch, J., Lees, M. \& Sloane-Stanley, G. H. (1957). A simple method for the isolation and purification of total lipids from animal tissues. Biological Chemistry 226, 497-509.

Fuller, R., Barrow, P. A. \& Brooker, B. E. (1978). Bacteria associated with the gastric epithelium of neonatal pigs. Applied and Environmental Microbiology 35, 582-591.

Henriksson, A., Sezwzyk, R. \& Conway, P. L. (1991). Characteristics of the adhesive determinants of Lactobacillus fermentum 104. Applied and Environmental Microbiology 57, 499-502.

JeNTOFT, N. \& DeARBoRN, D. G. (1979). Labeling of proteins by reductive methylation using sodium cyanoborohydride. Journal of Biological Chemistry 254, 4359-4365.

SAVAGE, D. C. (1972). Association and physiological interaction of indigenous microorganisms and gastrointestinal epithelia. American Journal of Clinical Medicine 25, 1372-1379.

Sherman, L. \& Savage, D. C. (1986). Lipoteichoic acids in Lactobacillus strains that colonize the mouse gastric epithelium. Applied and Environmental Microbiology 52, 302-304.

SMITH, W. H. (1965). Observations on the flora of the alimentary tract of animals and factors affecting its composition. Journal of Pathological Bacteriology 89, 95-122.

WAdSTRöM, T., ANDERsson, K., Sydow, M., AxelsSon, L., Lindgren, S. \& Gullmar, B. (1987). Surface properties of lactobacilli isolated from the small intestine of pigs. Journal of Applied Bacteriology 62, 513-520. 